\title{
Bio-reductive Synthesis and Characterization of Plant Protein Coated
}

\section{Magnetite Nanoparticles}

\author{
Amlan Kumar Das ${ }^{a}$, Avinash Marwal ${ }^{b}$ and Ruchi Verma ${ }^{c}$ \\ Department of Science and Humanities, Faculty of Engineering and Technology (FET), Mody \\ University of Science and Technology, Lakshmangarh, Sikar - 332311, Rajasthan, India. \\ Email: ${ }^{a *}$ amlan_snigdha@yahoo.com (corresponding author), ${ }^{b}$ marwal_avinash@yahoo.co.in, \\ cer.ruchiverma@gmail.com
}

Keywords: Bio-reductive, protein coated magnetite nano-bio hybrid, Datura inoxia.

\begin{abstract}
Over the past two decades, there have been increased emphases on the topic of green chemistry and chemical processes. Utilization of non toxic chemicals, environmentally benign solvents, and renewable materials are some of the key issues that merit important consideration in a green synthetic strategy. The Datura Inoxia leaves possesses biomolecules such as cardiac glycosides, proteins, phenolic compounds, flavonoids and sugar, which could be used as reducing agent to react with ferrous and ferric ions and as scaffolds to direct the formation of $\mathrm{Fe}_{3} \mathrm{O}_{4} \mathrm{NPs}_{\mathrm{s}}$ in solution. To the best of our knowledge, the use of Dhatura innoxia plant extract at room temperature for the bio-reductive synthesis of $\mathrm{Fe}_{3} \mathrm{O}_{4}$ nanoparticles has not been reported. The formation of the $\mathrm{Fe}_{3} \mathrm{O}_{4}$ magnetic nano particles was first monitored using UV-Vis absorption spectroscopy. FT-IR spectroscopy and TGA/DTG analysis further confirms the formation of plant protein coated magnetite nano-bio hybrid. The dried form of synthesized nanoparticles was further characterized using XRD, TEM.
\end{abstract}

\section{Introduction}

Magnetic nanosized particles have already been known for over 50 years, but research into their potential use in medicine and pharmaceutics is now the hot topic in this domain $[1,2,3]$. The unique combination of high magnetization and paramagnetic behaviour opens these materials to a 
very wide range of applications. Particularly, the possibilities of nanoparticle modification by biologically active compounds to use them in controlled drug delivery systems, as agents in magnetic resonance imaging and for magnetic-induced tumor treatment via hyperthermia are very interesting [4]. Iron oxide based nanoparticles belong to the most widely used materials in this field, although they have worse magnetic properties, lower saturation magnetization, and lower specific loss of power than $\mathrm{Fe}$ and Co nanoparticles which have just started to gain attention for biomedical purposes, too [5]. However, iron oxides have several advantages over Fe and Co nanoparticles, e.g., better oxidative stability, compatibility in nonaqueous systems, and nontoxicity. Among the four well-known crystalline polymorphs of iron(III) oxide $\left(\alpha-\mathrm{Fe}_{2} \mathrm{O}_{3}\right.$ as hematite, $\beta-\mathrm{Fe} 2 \mathrm{O} 3, \gamma-\mathrm{Fe}_{2} \mathrm{O}_{3}$ as maghemite and $\varepsilon-\mathrm{Fe}_{2} \mathrm{O}_{3}$ ), maghemite has gained the greatest interest in above mentioned applications [6]. Moreover, magnetite $\mathrm{Fe}_{3} \mathrm{O}_{4}$ is also very promising candidate as it is biocompatible and biodegradable [7, 8]. Several methods are generally employed for iron oxide nanoparticle preparation, including co precipitation [9], which is preferred due to its simplicity. On the other hand, thermal decomposition [10] seems to give the best control of nanoparticles size and morphology. The resulting physico-chemical properties of nanosized magnetic product obviously depend strongly on the fabrication conditions, especially on material origin, concentration and $\mathrm{pH}$ of solution as well as on the mode of thermal treatment used (annealing temperature, atmosphere and rate of heating/cooling). It was found that ferromagnetic low temperature phase $\gamma-\mathrm{Fe}_{2} \mathrm{O}_{3}$ can be easily transformed into the antiferromagnetic more stable phase $\alpha-\mathrm{Fe}_{2} \mathrm{O}_{3}$ when the temperature exceeds $500{ }^{\circ} \mathrm{C}$ [11]. Thus it is extremely important to optimize the preparation procedure in order to prevent formation of undesired product(s). The particle size also plays a crucial role. Typical particle sizes for the ferro- to superparamagnetic phase transformation are between 10 and $20 \mathrm{~nm}$ for oxides and 1-3 nm for metals [12]. Morales et al. observed that the use of polymers in the material synthesis limits the particle size [13]. Ultrasmall magnetic iron oxide nanoparticles $(<5$ $\mathrm{nm}$ ) with very uniform size distribution can be also synthesized using the water-in-oil microemulsion method [14]. 
Currently, a large number of physical, chemical, biological, and hybrid methods are available to synthesize different types of nanoparticles [15]. The nanoparticles formed using each method show specific properties. However, biosynthesis of metal nanoparticles by plants is currently under development. Green nanotechnology has attracted a lot of attention and includes a wide range of processes that reduce or eliminate toxic substances to restore the environment. The synthesis of metal nanoparticles using inactivated plant tissue [16], plant extracts [17], exudates [18], and other parts of living plants [19] is a modern alternative for their production. Green synthesis of nanoparticles makes use of environmental friendly, non-toxic and safe reagents [20].

The green method of synthesis of nano particles is easy, efficient, and eco-friendly in comparison to chemical-mediated synthesis $[21,22,23,24]$. The chemical synthesis involves toxic solvents, high pressure, energy and high temperature conversion and microbe involved synthesis is not feasible industrially due to its lab maintenance. Since, green synthesis is the best option to opt for the synthesis of nanoparticles, therefore the magnetite nanoparticles are synthesized by using aqueous extract of Datura inoxia and ferrous and ferric ions. Magnetite was of particular interest due to its unique magnetic and electrical properties. Datura inoxia leaf extract was selected as it is of high medicinal value and it does not require any sample preparation and hence is cost-effective. To the best of our knowledge, the use of Datura inoxia plant extract at room temperature for the green synthesis of protein coated magnetite nano-bio hybrid has not been reported.

Datura inoxia (family Solanaceae) is a common hallucinogenic alkaloid containing toxic annual weed, found in India. It is also use as an ornamental plant for its large leaves and large white flower. The native range of Datura inoxia appears to have Mexico and the U.S. Southwest, India, and China [25]. Further Datura species are widely distributed in tropical and temperate regions of both hemispheres [26]. The plant has been used to treat asthma, diarrhea, as an analgesic, to control fever, kill parasites, and as a drug for clinical purposes [27]. 
In this present study it has been found that the proteins available in the plant extract have been found to be very effective stabilizing agent by forming a coating on the surface of the nano particle besides being acting as reducing agent for the formation of magnetite nano particles. These greensynthesized nano particles were examined by ultraviolet-visible spectroscopy; transmission electron microscopy (TEM), and X-ray analysis (XRD) to determine their size and shape; TGA and FTIR analysis were also performed to confirm the protein coating on nano particle forming protein coated magnetite nano-bio hybrid.

\section{Materials and Methods}

Preparation of Aqueous Leaf Extract of Datura Inoxia. Fresh leaves of Datura inoxia were washed under running tap water to remove any debris and dust attached to the leaves and subsequently with Millipore water 3-4 times [28]. Leaves were air dried for two weeks at room temperature $\left(25^{\circ} \mathrm{C}\right)$. The dried leaves were finely powdered through grinding using Lumix grinder. The extract was prepared by taking $40 \mathrm{~g}$ of powdered leaves in a $500 \mathrm{~mL}$ round flask with $300 \mathrm{~mL}$ of sterile Millipore water. Then the above was boiled for $10 \mathrm{~min}$ and sieved and filtered twice by using Watman filter paper No 42. The filtrate was collected and stored at $4{ }^{\circ} \mathrm{C}$ and used within a week. Small amount of filtrate was dried at $80^{\circ} \mathrm{C}$ and analyzed by FT-IR techniques [29].

Phytochemical Analysis. Qualitative phytochemical analysis of the leaf extract was performed following standard procedure available in the literature $[30,31,32]$. The result of all the analysis has been tabulated in the result and discussion section.

Nanoparticles Synthesis. Ferric (III) chloride, Ferrous (II) chloride and $\mathrm{NaOH}$ were purchased from $\mathrm{CDH}$, and the aqueous leaves extract of Datura inoxia was used for the bioreduction process. To synthesize nanoparticles from Datura inoxia, $0.53 \mathrm{gm}$ of Ferrous chloride tetra hydrate $\left(\mathrm{FeCl}_{2} \cdot 4 \mathrm{H}_{2} \mathrm{O}, \mathrm{AR}\right)$ and 1.11 gm of Ferric chloride hexa hydrate $\left(\mathrm{FeCl}_{3} \cdot 6 \mathrm{H}_{2} \mathrm{O}, \mathrm{AR}\right)$ after weighing is dissolved in $100 \mathrm{ml}$ of sterile deionised water in a $250 \mathrm{ml}$ beaker. The mixture is heated at $80 \mathrm{oC}$ 
under mild stirring. After 10 minutes when the plate of stirrer gets heartened up, $5 \mathrm{~mL}$ of the aqueous solution of leaf extract was added to the above solution drop wise. After few minutes the initial colour of the mixture becomes darker. Further $20 \mathrm{ml}$ of $1 \mathrm{M} \mathrm{NaOH}(0.8 \mathrm{gms})$ was measured and dissolved with sterile deionized water in a beaker and added drop wise to the solution. A change in color of the colloidal solutions and precipitation occurred, confirming green synthesis of Ferric oxide (Fe3O4) nanoparticles.

Characterization of Nanoparticles. Magnetite (Fe3O4) nanoparticles synthesized by this green method were initially examined using Carry 60 Agilent UV - vis spectrophotometer. FT-IR spectroscopy of Datura inoxia leaf extract and magnetite nanoparticles was carried out in the range 4000-400 $\mathrm{cm}^{-1}$ by Perkin Elmer FT-IR spectrophotometer which confirmed that the protein present in the extract has the ability to act as reducing agent and stabilizer for $\mathrm{Fe} 3 \mathrm{O} 4$ nano particles forming protein coated magnetic nano-bio hybrid. X-ray diffraction and TEM images were also taken to identify the nature of crystal and particle size respectively. Thermogravimetric analysis (TGA) was performed under nitrogen atmosphere at a heating rate of $10{ }^{\circ} \mathrm{C} / \mathrm{min}$ from room temperature up to $700{ }^{\circ} \mathrm{C}$ which further confirms the protein coating on the magnetite surface.

\section{Result and Discussion}

The Datura inoxia leaves material was collected from the location Latitude: $27 \mathrm{~N} 48^{\prime} 15.64$ and Longitude: 75E 01' 51.36” (FET, MUST University, Lakshmangarh, Sikar district of Rajasthan province of India). The leaves were dried and later finely powdered for extraction of phytochemicals present in it (Fig. 1). 


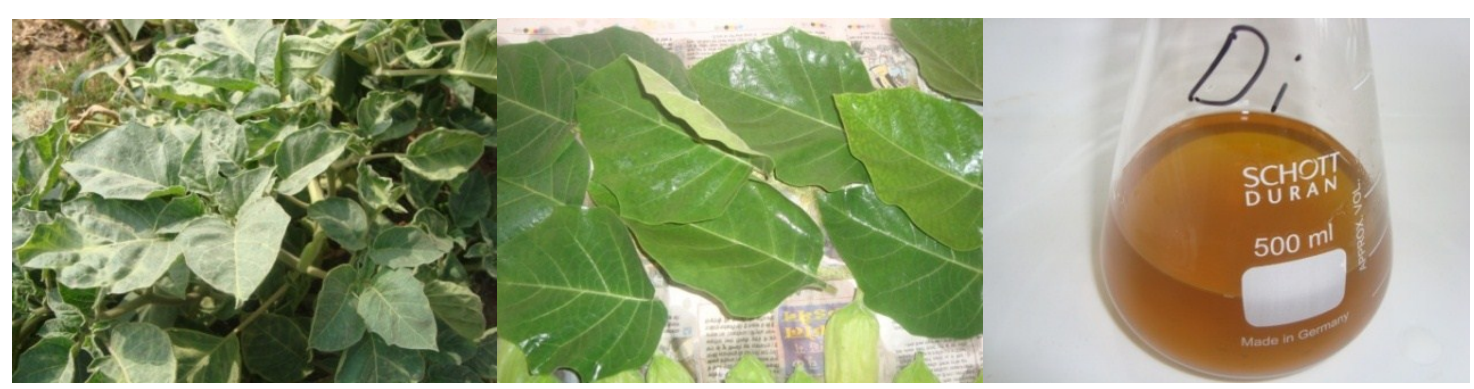

(a)

(b)

(c)

Fig. 1. (a) Datura inoxia naturally growing near the vicinity of FET, Lakshmangarh, Sikar district of Rajasthan province of India, (b) Millipore washed leaves were room dried for two weeks, (c) Leaves extract revealed brown color.

Bio-reductive green-synthesized Ferric oxide (Fe3O4) nano-bio hybrid was produced by treating ferric ions with the leaves extract of Datura inoxia. Ferric chloride was taken as the metal precursor in the present experiments whereas leaves extract act as a reducing as well as a stabilizing agent. The color change was noted by visual observation in the Schott Duran beaker which contains Ferric chloride solution with Datura inoxia leaves extract. The color of the Ferric chloride / leaves extract solution changed from light brown to dark brown after $5 \mathrm{~min}$. This color change indicates the formation of $\mathrm{Fe} 3 \mathrm{O} 4$ magnetic nanoparticles in the solution. The initial $\mathrm{pH}$ of the leaf extract was 5.03, whereas that of Ferric and Ferrous chloride was 3. The final $\mathrm{pH}$ after the completion of reaction was observed as 10 .

The plant was tested for the presence of phytochemicals. The aqueous extract of Datura inoxia was evaluated for the presence of various phyto constituents by performing a series of qualitative chemical tests. Ten phytochemicals test were performed, out of which five were present in the leaf extracts of Datura inoxia (Table 1). 
Table 1. Presence or absence of phytochemicals in leaves extract of Datura inoxia.

\begin{tabular}{|l|l|l|}
\hline S.No. & Phytochemicals & Occurrence \\
\hline 1 & Tannins & No \\
\hline 2 & Saponin & No \\
\hline 3 & Cardiac Glycosides & Yes \\
\hline 4 & Phenolic compounds & Yes \\
\hline 5 & Flavonoids & Yes \\
\hline 6 & Alkaloids & No \\
\hline 7 & Sugars & Yes \\
\hline 8 & Proteins & Yes \\
\hline 9 & Starch & No \\
\hline 10 & Phytosterol & No \\
\hline
\end{tabular}

The phytochemicals present in the leaf extracts act as reducing agents, which include protein, ardiac Glycosides, Phenolic compounds, Flavanoids and Sugars. The aqueous Datura inoxia leaf extracts was found to have these contents, suggesting they are the most favorable starting material for preparation of protein coated $\mathrm{Fe}_{3} \mathrm{O}_{4}$ magnetic nano-bio hybrid.

The formation of $\mathrm{Fe}_{3} \mathrm{O}_{4}$ magnetic nanoparticles was further confirmed by using UV-visible spectroscopy (UV-vis), Fourier-Transform infrared spectroscopy (FTIR), X-ray diffraction (XRD) and transmission electron microscopy (TEM). The formation of the Fe3O4 nanoparticles was first monitored using UV-Vis absorption spectroscopy. The UV-Vis spectroscopy revealed the formation of $\mathrm{Fe}_{3} \mathrm{O}_{4}$ nanoparticles by exhibiting the typical surface plasmon absorption maxima at $290 \mathrm{~nm}$ [33]. The characteristic peak around $290 \mathrm{~nm}$ was obtained (Fig. 2) ; confirming the synthesis of $\mathrm{Fe}_{3} \mathrm{O}_{4}$ nanoparticles. No other peak was observed in the spectrum which confirms that the synthesized products are magnetic $\mathrm{Fe}_{3} \mathrm{O}_{4}$ only. Generally, biosynthetic methods are considered as 
time consuming when compared with chemical methods. To the best of our knowledge, reaction time of 15 mins is required to prepare plant protein mediated nano-bio hybrid.

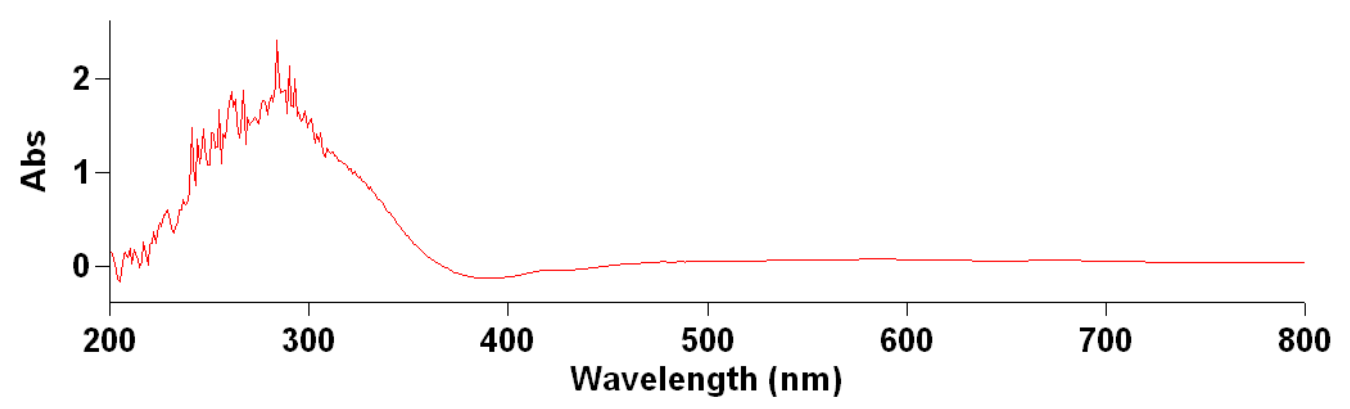

Fig. 2. UV - visible spectrum of solution after treatment with leaf extracts.

The colloidal solutions were dried in watch glasses to analyze the samples. The dried form of synthesized $\mathrm{Fe}_{3} \mathrm{O}_{4}$ magnetic nanoparticles as well dried form of leaves extract of Datura inoxia was further characterized using Fourier transform infrared (FTIR) spectroscopy. The FTIR measurement was carried out to identify the possible biomolecules responsible for capping and reducing agent for the $\mathrm{Fe}_{3} \mathrm{O}_{4}$ magnetic nanoparticles synthesized by leaves extract of Datura inoxia. The FTIR study confirms the protein coating on nano particle forming protein coated magnetite nano-bio hybrid. FTIR spectroscopy was used to identify the functional groups of the active components based on the peak value in the region of infrared radiation (Table 2 and Table 3). Fig. 3, shows FTIR spectra of Datura inoxia powder and Fe3O4 magnetic nanoparticles. The shift in band from $3417.44 \mathrm{~cm}-1$ to $3437.14 \mathrm{~cm}-1$ shows the involvement of the $-\mathrm{OH}$ group in the stabilization process. The strong band at $1640.11 \mathrm{~cm}^{-1}$ and the shoulder peak at $1411.06 \mathrm{~cm}-1$ are identified as the amide I and amide II of the protein, which arise due to $-\mathrm{C}=\mathrm{O}$ and $-\mathrm{NH}$ stretching vibrations in the amide linkage of the protein. The shift of the band from $1,640.11 \mathrm{~cm}-1$ to $1,639.21 \mathrm{~cm}^{-1}$ was attributed to the binding of a $-\mathrm{C}=\mathrm{O}$ group with the nanoparticles. 
Table 2. FTIR bands and functional groups of dried extracts of Datura inoxia.

\begin{tabular}{|l|l|l|l|}
\hline BANDS $\left(\mathrm{cm}^{-1}\right)$ & FUNCTIONAL GROUP & TYPE OF & INTENSITY \\
\hline 3417.44 & Alcohol OH & StBRATION & \\
\hline 1640.11 & Amide C=O & Stretch & Strong broad \\
\hline 1411.06 & NH & Stretch & wedium- \\
\hline 1385.65 & Alkyl halide C-F & Stretch & Medium- \\
\hline 1321.45 & Alkyl halide C-F & Stretch & weak,multiple bonds \\
\hline 1110.26 & Ether C-O & Stretch & Strong \\
\hline 837.45 & Alkene $=$ C-H & Bending & Strong \\
\hline 765.09 & Alkyl halide C-Cl & Stretch & Strong \\
\hline 617.97 & Alkyl halide C-Cl & Stretch & Strong \\
\hline 521.92 & Alkyl halide C-Br & Stretch & \\
\hline
\end{tabular}

Table 3. FTIR bands and functional groups of magnetite nanoparticles.

\begin{tabular}{|l|l|l|l|}
\hline BANDS $\left(\mathrm{cm}^{-1}\right)$ & FUNCTIONAL GROUP & TYPE OF & INTENSITY \\
\hline 3437.14 & Alcohol OH & Stretch, H-bonded & Strong broad \\
\hline 1639.21 & Amide C=O & Stretch & Strong \\
\hline 1564.26 & Aromatic C=C & Stretch & Medium-weak, \\
& & & multiple bonds \\
\hline 1414.04 & Assymetric COO- & Stretch & Strong \\
\hline 1020.48 & Symmetric COO- & Stretch & Strong \\
\hline 583.45 & Fe-O & Stretch & \\
\hline
\end{tabular}


FT-IR spectroscopy confirmed that the leaf extract has the ability to act as reducing agent and stabilizer for magnetite nanoparticles. The peaks at 1414.04 and $1020.48 \mathrm{~cm}^{-1}$ are attributed to the asymmetric and symmetric stretching vibration of COO-. The FTIR spectrum of DI powder has a characteristic stretching vibration band at $1321.45 \mathrm{~cm}^{-1}$ denoting the asymmetric stretching vibration of the Amine -C-N group, which disappeared after synthesis of $\mathrm{Fe}_{3} \mathrm{O}_{4}$ magnetic nanoparticles. The band at $1110.26 \mathrm{~cm}^{-1}$ can be assigned to the symmetric $\mathrm{C}-\mathrm{O}$ vibration associated with a $\mathrm{C}-\mathrm{O}-\mathrm{CN}$ group. The FTIR study confirms the protein coating on nano particle forming protein coated magnetite nano-bio hybrid.

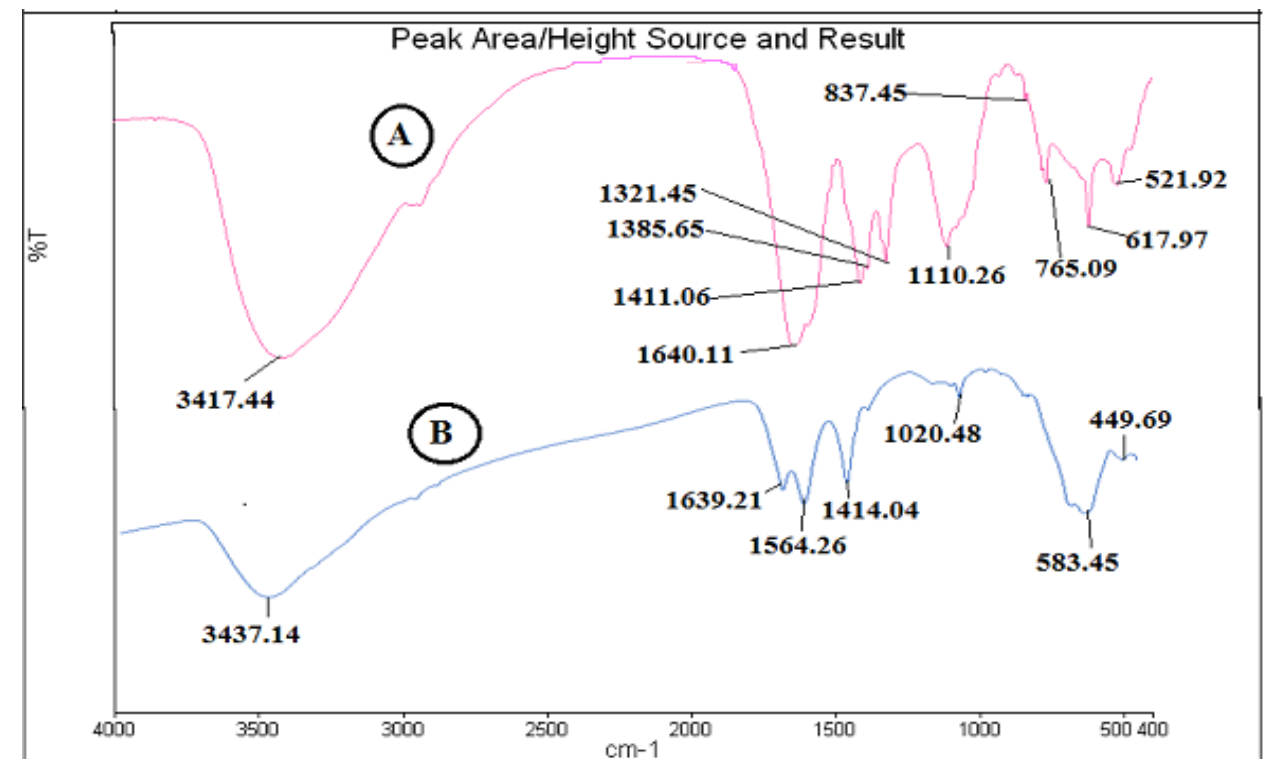

Fig. 3. (A) FTIR spectrum of dried aqueous extract of Datura inoxia leaves, (B) FTIR spectrum of synthesize $\mathrm{Fe}_{3} \mathrm{O}_{4}$ magnetic nanoparticles.

The presence of magnetite nanoparticles can be seen by two strong absorption bands at around 583.45 and $449.69 \mathrm{~cm}^{-1}$ which, corresponding to the $\mathrm{Fe}-\mathrm{O}$ stretching band of bulk magnetite $\left(\mathrm{Fe}_{3} \mathrm{O}_{4}\right)$. These results revealed that the $\mathrm{C}=\mathrm{O}$ groups were bonded on the magnetite particle surface. Overall the observation confirms the presence of protein in leaf extract, which acts as a reducing agent and stabilizer for magnetite nanoparticles.

Ferric chloride $\mathrm{FeCl}_{3} \cdot 6 \mathrm{H}_{2} \mathrm{O}$ and ferrous chloride $\mathrm{FeCl}_{2} \cdot 4 \mathrm{H}_{2} \mathrm{O}$ and Datura inoxia leaf extract are in one aqueous phase in the reaction system. The $\mathrm{C}=\mathrm{O}$ of amide group in Datura inoxia leaf extract 
chelated with $\mathrm{Fe}^{3+}$ and $\mathrm{Fe}^{2+}$ to form ferric and ferrous Protein. With heating, $\mathrm{OH}-$ of $\mathrm{NaOH}$ would be involved in the reaction. A competition between of $\mathrm{C}=\mathrm{O} \ldots . . \mathrm{Fe}^{3+}$ and $\mathrm{C}=\mathrm{O} \ldots . . \mathrm{Fe}^{2+}$ bonds and the formation of $\mathrm{HO}^{-} \ldots \mathrm{Fe}^{3+}$ and $\mathrm{OH}-\ldots \mathrm{Fe}^{2+} \ldots$ bonds and a result of formation of ferric hydroxide, $\mathrm{Fe}(\mathrm{OH}) 3$ and ferrous hydroxide, $\mathrm{Fe}(\mathrm{OH})_{2}$. The formation of ferric hydroxide and ferrous hydroxide form a shell core structure with Protein chain of Datura inoxia leaf extract as core. Ferric hydroxide and ferrous hydroxide in core dehydrated $\left(-\mathrm{H}_{2} \mathrm{O}\right)$ forming protein coated magnetite $\left(\mathrm{Fe}_{3} \mathrm{O}_{4}\right)$ nanobio hybrid crystals. The shell of Protein of Datura inoxia leaf extract chains attached on $\mathrm{Fe}_{3} \mathrm{O}_{4}$ surface through chelation of $\mathrm{C}=\mathrm{O} \ldots \mathrm{Fe}^{3+}$ and $\mathrm{C}=\mathrm{O} \ldots \mathrm{Fe}^{2+}$ at the end of the reaction, $\mathrm{Fe}_{3} \mathrm{O}_{4}$ nano-bio hybrid crystals were capped and stabilized by Protein chain of Datura inoxia leaf extract. The formation mechanism has been discussed on the light of the discussion available in reference [21].

$\mathrm{XRD}$ is an effective characterization to confirm the crystal structure of the synthesized protein coated $\mathrm{Fe} 3 \mathrm{O} 4$ nano-bio hybrid. Magnetite (Fe3O4) nano particles synthesized by this green method were examined by $\mathrm{X}$-ray powder diffraction equipped with $\mathrm{CuK} \alpha$ radiation source using $\mathrm{Ni}$ as filter at a setting of $45 \mathrm{kV} / 40 \mathrm{~mA}$. All XRD data were collected under the experimental conditions in the angular range $5^{\circ} \leq 2 \theta \leq 90^{\circ}$. Ten characteristic peaks at $27.5,30.3,31.8,35.7,43.5,45.5,57.4,63.0$, 75.6 and 84.1 were corresponding to the (210), (211), (211), (220), (311), (222), (331), (422), (440) and (442) crystal planes of a pure Fe3O4 matched well with that of it JCPDS file No. 82-1533 indicating that sample has a cubic crystal system with no characteristics peaks of impurities were observed (Fig. 4). 


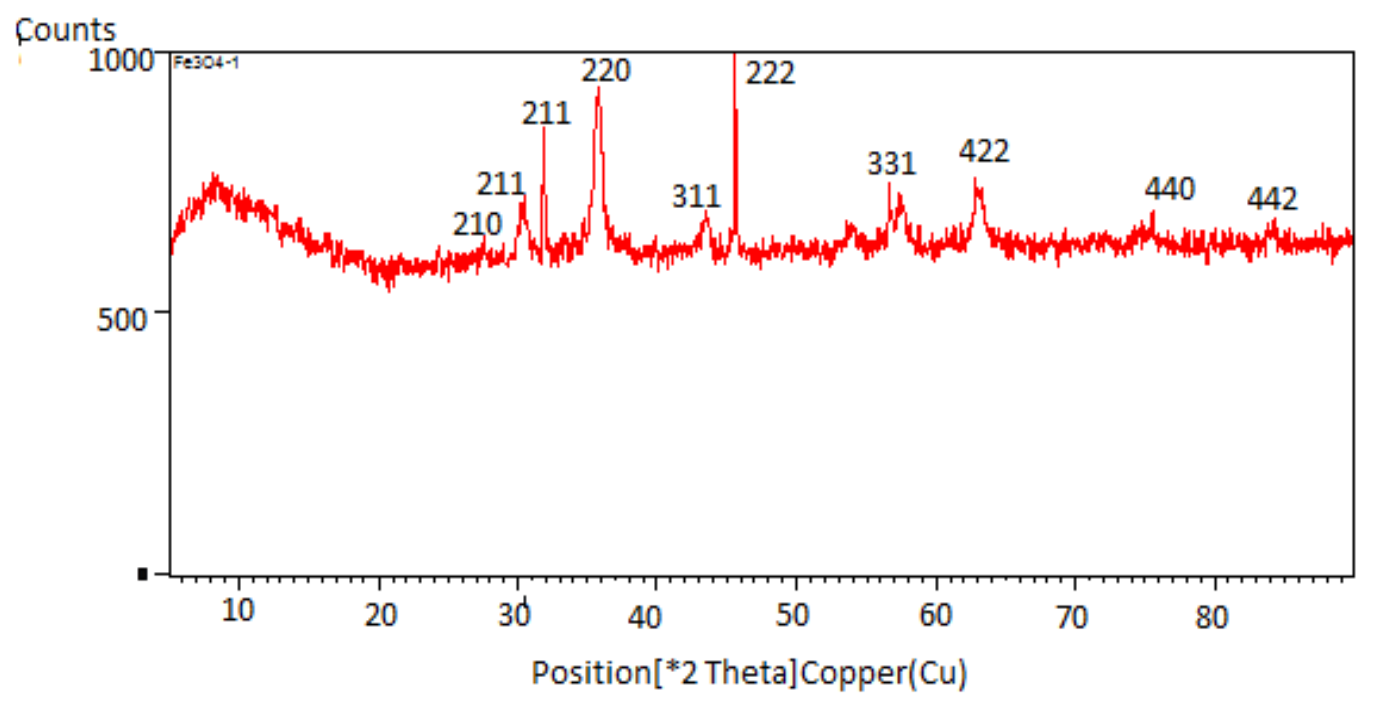

Fig. 4. XRD pattern of the synthesized protein coated $\mathrm{Fe}_{3} \mathrm{O}_{4}$ nano-bio hybrid by bioreductive method.



Fig. 5. TEM image of $\mathrm{Fe}_{3} \mathrm{O}_{4}$ nanoparticles (uniform size distribution and most of $\mathrm{Fe}_{3} \mathrm{O}_{4}$ nanoparticles are approximately cubic, with mean diameters ranging from 7-14 nm). 
The transmission electron microscopy (TEM) micrograph for synthesized protein coated $\mathrm{Fe} 3 \mathrm{O} 4$ nano-bio hybrid is shown in Fig. 5. The particles had a rather narrow size distribution, where most of the Fe3O4 particles were within 7-14 nm. Therefore the Fe3O4 nanoparticles were successfully synthesized by this green method using Datura inoxia leaf extract as reducing agent and stabilizer forming protein coated magnetic nano-bio hybrid.



Fig. 6. Thermogravimetric analysis (TGA) results of magnetic nanoparticles.

Fig. 6 revealed the TGA results for these magnetic nanoparticles. An initial weight loss of $6.11 \%$ around $120{ }^{\circ} \mathrm{C}$ was occurred, followed by $9.66 \%, 2.36 \%$ and $5.45 \%$ at $340{ }^{\circ} \mathrm{C}, 510{ }^{\circ} \mathrm{C}$ and $699{ }^{\circ} \mathrm{C}$ respectively. The final residual left was $76.39 \%$, thus confirming that the protein was conjugated to the magnetic naoparticles forming the nano-protein hybrid. The initial weight loss of magnetite nanoparticles powder under $100{ }^{\circ} \mathrm{C}$ is likely to be caused by the contained water. The protein of Datura inoxia leaf extract decomposes completely at temperature higher than $600{ }^{\circ} \mathrm{C}$ and the residual weight of magnetite nanoparticles is $76.39 \%$ at $700{ }^{\circ} \mathrm{C}$. The results of TGA illustrated that there is amide I and amide II in Datura inoxia leaf extract in the magnetite nanoparticles with 
weight is around 34\%. Overall the TGA demonstrated that Datura inoxia leaf extract existed on the surface of magnetite nanoparticles.

\section{Conclusion}

In the present study we report a green approach for the synthesis of protein coated $\mathrm{Fe} 3 \mathrm{O} 4$ magnetic nano-bio hybrid using leaves extracts of Datura inoxia containing protein which have been found to be very effective stabilizing agent by forming a coating on the surface of the nano particle besides being acting as reducing agent for the formation of magnetite nano bio-hybrid. The Datura inoxia aqueous leaves extract appears to be environmentally friendly, so that this protocol could be used for rapid production of $\mathrm{Fe} 3 \mathrm{O} 4$ magnetic nanoparticles. This is a simple, green and efficient method to synthesize $\mathrm{Fe} 3 \mathrm{O} 4$ magnetic nanoparticles at room temperature without using any harmful reducing agents and any capping or dispersing agent. In the future, selection of such plants may create a new platform for realizing the potential of herbal medicines in nano science for drug delivery and biomedical application. This is a preliminary study of the biological mechanism for biosynthesis of nanoparticles.

\section{Acknowledgements}

Thanks are due to the Department of Atomic Energy (DAE) - Board of Research in Nuclear Sciences (BRNS), Mumbai, India for their financial support. Facilities extended by Nano Science and Chemistry Research Laboratory, Faculty of Engineering and Technology of Mody University of Science and Technology, Lakshmangarh are gratefully acknowledged. 


\section{References}

[1] J. Drbohlavova, R. Hrdy, V. Adam, R. Kizek, O. Schneeweiss and J. Hubalek, Preparation and Properties of Various Magnetic Nanoparticles, Sensors 9 (2009) 2352-2362.

[2] M. Arruebo, R. Fernandez-Pacheco, M.R.Ibarra,J. Santamaria, Magnetic nanoparticles for drug delivery, Nano Today 2(2007) 22-32.

[3] A.H. Lu, E.L. Salabas, F. Schuth, Magnetic nanoparticles: Synthesis, protection, functionalization, and application. Angew. Chem. Int. Edit. 46 (2007) 1222-1244.

[4] C.S.S.R. Kumar, Biofunctionalization of Nanomaterials; Wiley-VCH: Weinheim, Vol. 1, (2005) pp. 72-98.

[5] Hutten, D. Sudfeld, I. Ennen, G. Reiss, W. Hachmann, U. Heinzmann, K.Wojczykowski, P. Jutzi, W. Saikaly, G.Thomas, New magnetic nanoparticles for biotechnology, J. Biotechnol. $112(2004)$ 47-63.

[6] J. Tucek, R. Zboril, D. Petridis, Maghemite nanoparticles by view of Mossbauer spectroscopy. J. Nanosci. Nanotechnol. 6 (2006) 926-947.

[7] A.K.Gupta, M. Gupta, Synthesis and surface engineering of iron oxide nanoparticles for biomedical applications, Biomaterials 26 (2005) 3995-4021.

[8] J. Xie, C.J. Xu, Z.C. Xu, Y.L.Hou, K.L.Young, S.X.Wang, N. Pourmond, S.H.Sun, Linking hydrophilic macromolecules to monodisperse magnetite (Fe3O4) nanoparticles via trichloros-triazine, Chem. Mater. 18 (2006) 5401-5403.

[9] D.P. Tang, R. Yuan, Y.Q. Chai, Direct electrochemical immunoassay based on immobilization of protein-magnetic nanoparticle composites on to magnetic electrode surfaces by sterically enhanced magnetic field force, Biotechnol. Lett. 28 (2006) 559-565.

[10] R. Zboril, M. Mashlan, D. Petridis, Iron(III) oxides from thermal processes-synthesis, structural and magnetic properties, Mossbauer spectroscopy characterization, and applications, Chem. Mater. 14 (2002) 969-982. 
[11] D. Ortega, J.S. Garitaonandia, C. Barrera-Solano, M. Ramirez-Del-Solar, E. Blanco, M. Dominguez, Gamma-Fe2O3/SiO2 nanocomposites for magneto-optical applications: Nanostructural and magnetic properties, J. Non-Cryst. Solids 352 ( 2006) 2801-2810.

[12] X. Batlle, A. Labarta, Finite-size effects in fine particles: magnetic and transport properties, J. Phys. D: Appl. Phys. 35 (2002) R15-R42.

[13] M.A. Morales, P.V. Finotelli, J.A.H. Coaquira, M.H.M. Rocha-Leao, C. Diaz-Aguila, E.M. Baggio-Saitovitch, A.M. Rossi, In situ synthesis and magnetic studies of iron oxide nanoparticles in calcium-alginate matrix for biomedical applications, Mater. Sci. Eng. CBiomimetic Supramol. Syst.28 (2008) 253-257.

[14] S. Santra, R. Tapec, N. Theodoropoulou, J. Dobson, A. Hebard, W.H. Tan, Synthesis and characterization of silica-coated iron oxide nanoparticles in microemulsion: The effect of nonionic surfactants, Langmuir 17 (2001) 2900-2906.

[15] J. Liu, S.Z. Qiao, Q.H. Hu, G.Q. Lu, Magnetic nanocomposites with mesoporous structures: synthesis and applications, Small 7 (2001) 425-443.

[16] V.V. Padil, M. Cerník, Green synthesis of copper oxide nanoparticles using gum karaya as a biotemplate and their antibacterial application, Int. J. Nanomedicine 8 (2013) 889-898.

[17] K. Shameli, M.B. Ahmad, A. Zamanian, P. Sangpour, P. Shabanzadeh, Y. Abdollahi, M. Zargar, Green biosynthesis of silver nanoparticles using Curcuma longa tuber powder, Int. J. Nanomedicine 7 (2012) 5603-5610.

[18] A.I. Lukman, B. Gong, C.E. Marjo, U. Roessner, A.T. Harris, Facile synthesis, stabilization, and anti-bacterial performance of discrete Ag nanoparticles using Medicago sativa seed exudates, J. Colloid Interface Sci. 353 (2011) 433-44.

[19] J.G. Parsons, J.R. Peralta-Videa, J.L. Gardea-Torresdey, Use of plants in biotechnology: Synthesis of metal nanoparticles by inactivated plant tissues, plant extracts, and living plants, Dev. Environ. Sci. 5 (2007) 463-485. 
[20] H.A. Salam, P. Rajiv, M. Kamaraj, P. Jagadeeswaran, S. Gunalan, R. Sivaraj, Plants: Green route for nanoparticle synthesis, Int. J. Biol. Sci. 1 (2012) 85-90.

[21] A.M. Awwad, N.M. Salem, A Green and Facile Approach for Synthesis of Magnetite Nanoparticles, J. Nanosci. Nanotechnol. 2 (2012) 208-213.

[22] M. Mahdavi, F. Namvar, M.B. Ahmad, R. Mohamad, Green Biosynthesis and Characterization of Magnetic Iron Oxide (Fe3O4) Nanoparticles Using Seaweed (Sargassum muticum) Aqueous Extract, Molecules 18 (2013) 5954-5964.

[23] M. Pattanayak, P.L. Nayak, Ecofriendly green synthesis of iron nanoparticles from various plans and spices extract, International Journal of Plant, Animal and Environmental Sciences $3(2013) 68-78$.

[24] M. Senthil, and C. Ramesh, Biogenic synthesis of Fe3O4 nano particles using tridax procumbens leaf extract and its antibacterial activity on pseudomonas aeruginosa, Digest Journal of Nanomaterials \& Biostructures (DJNB), 7 (2012) 1655.

[25] R.E. Schultes, and A. Hofmann, Their Sacred, Healing and Hallucinogenic Powers. In: Plants of the Gods, Healing Arts Press, New York, (1992) 192.

[26] A.M. Kinsara, and M.M. Seif El - Nasr, Organization and alkaloid production in tissue culture of Datura inoxia Mill, JKAU Sci. 6 (1994) 5-15.

[27] K. Bonde, The Genus Datura: From Research Subject to Powerful Hallucinogen http://leda.lycaeum.org/?ID=16212. 2001.

[28] S. Ghosh, S. Patil, M. Ahire, R. Kitture, D.D. Gurav, A.M. Jabgunde, S. Kale, K. Pardesi, V. Shinde, J. Bellare, D.D. Dhavale, B.A. Chopade, Gnidia glauca flower extract mediated synthesis of gold nanoparticles and evaluation of its chemocatalytic potential, Journal of Nanobiotechnology 10:17 (2012) (9 pages).

[29] P. Kumar, P. Singh, K. Kumari, S. Mozumdar, R. Chandra, A green approach for the synthesis of gold nanotriangles using aqueous leaf extract of Callistemon viminalis, Materials Letters 65 (2011) 595-597. 
[30] J. Parekh, S.V. Chanda, In vitro Antimicrobial Activity and Phytochemical Analysis of Some Indian Medicinal Plants, Turk. J. Biol. 31 (2007) 53-58.

[31] K. Prabhu, P.K. Karar, S. Hemalatha, K. Ponnudurai, A comparative preliminary phytochemical screening on the leaves, stems and the roots of three viburnum Linn Species, Der Pharmacia Sinica 2 (2011) 81-93.

[32] P.R. Shinde, P.S. Patil, V.A. Bairagi, Pharmacognostic, phytochemical properties and antibacterial activity of Callistemon citrinus viminalis leaves and stems, International Journal of Pharmacy and Pharmaceutical Sciences 4 (2012) 406-408.

[33] M.F. Balandrin, A.J. Kjocke, and E. Wurtele, Natural plant chemicals: sources of industrial and mechanical materials, Science 228 (1985) 1154-1160. 